\title{
Forest Fragments Surrounded by Sugar Cane Are More Inhospitable to Terrestrial Amphibian Abundance Than Fragments Surrounded by Pasture
}

\author{
Paula Eveline Ribeiro D'Anunciação, ${ }^{1,2}$ Marcela Fernandes Vilela Silva, ${ }^{1,2}$ Lucas Ferrante, \\ Diego Santana Assis, ${ }^{2}$ Thamires Casagrande, ${ }^{2}$ Andréa Zalmora Garcia Coelho, ${ }^{2}$ \\ Bárbara Christina Silva Amâncio, ${ }^{2}$ Túlio Ribeiral Pereira, ${ }^{2}$ and Vinícius Xavier da Silva ${ }^{1,2}$ \\ ${ }^{1}$ Curso de Mestrado em Ecologia e Tecnologia Ambiental, Universidade Federal de Alfenas (Unifal-MG), \\ R. Gabriel Monteiro da Silva, 700, 37130-000 Alfenas, MG, Brazil \\ ${ }^{2}$ Laboratório de Ecologia de Fragmentos Florestais (ECOFRAG), Instituto de Ciências da Natureza (ICN), \\ Universidade Federal de Alfenas (Unifal-MG), R. Gabriel Monteiro da Silva, 700, 37130-000 Alfenas, MG, Brazil
}

Correspondence should be addressed to Paula Eveline Ribeiro D’Anunciação; paulaevel@yahoo.com.br

Received 26 July 2013; Revised 23 September 2013; Accepted 27 October 2013

Academic Editor: Simona Castaldi

Copyright (C) 2013 Paula Eveline Ribeiro D’Anunciação et al. This is an open access article distributed under the Creative Commons Attribution License, which permits unrestricted use, distribution, and reproduction in any medium, provided the original work is properly cited.

\begin{abstract}
In recent years, there has been increasing interest in matrix-type influence on forest fragments. Terrestrial amphibians are good bioindicators for this kind of research because of low vagility and high philopatry. This study compared richness, abundance, and species composition of terrestrial amphibians through pitfall traps in two sets of semideciduous seasonal forest fragments in southeastern Brazil, according to the predominant surrounding matrix (sugar cane and pasture). There were no differences in richness, but fragments surrounded by sugar cane had the lowest abundance of amphibians, whereas fragments surrounded by pastures had greater abundance. The most abundant species, Rhinella ornata, showed no biometric differences between fragment groups but like many other amphibians sampled showed very low numbers of individuals in fragments dominated by sugar cane fields. Our data indicate that the sugar cane matrix negatively influences the community of amphibians present in fragments surrounded by this type of land use.
\end{abstract}

\section{Introduction}

Species persistence in fragmented landscapes may heavily depend on their tolerance to the surrounding-environment matrix [1-3]. The surrounding matrix can influence resource availability [4], animal dispersion [5], habitat fragment occupation $[2,6]$, and also the distribution and population dynamics within the fragment $[1,7,8]$. Generally, the higher the structural similarity of the matrix with the fragment, the greater the gene flow and dispersion of animals [1], as well as the richness and abundance of mammals [9], birds [10], and amphibians [11].

The matrix importance to the response of species to fragmentation depends not only on its structural characteristics, but also species biology [12]. Amphibians are sensitive to environmental alterations, because most have a biphasic life cycle [13], permeable skin [14], low vagility [15], and strong philopatry [16]. Also, they have been suffering declines worldwide, mainly due to habitat loss, overutilization, and chytridiomycosis which is an infectious disease caused by fungus $[17,18]$.

In surveys focused on amphibians and matrices, there is predominance of studies with pastures. Deforestation for pasture establishment can lead to richness reduction and the predominance of generalist and terrestrial anurans [19]. The pasture matrix can also reduce reproductive success of Phyllomedusa tarsius [20], amphibian richness [21], and abundance [22]. Pastures negatively impact amphibians, especially large and terrestrial species whose eggs are deposited on land, but whose larvae develop in water [23]. 
Our goal was to compare terrestrial amphibian diversity and biometrics of the most abundant species between forest fragments under the influence of two predominant matrix types (sugar cane and pastures). Our premises are that amphibian diversity, the weight and length of the most abundant species, will be greater in the fragments surrounded by sugar cane plantations and the opposite in fragments with pastures. We assume this because a larger number of studies indicate negative effects of grazing on frogs and due to the scarcity of studies on sugar cane.

\section{Methods}

2.1. Study Site. We conducted the study in three citiesAlfenas, Areado and Serrania-in the state of Minas Gerais, southeastern Brazil, transitions between biomes of the Atlantic Forest, and Cerrado. The region has an average altitude of $880 \mathrm{~m}$, an average annual temperature of $23^{\circ} \mathrm{C}$, average annual rainfall of $1600 \mathrm{~mm}$, distributed evenly throughout the year, and an annual average $70 \%$ relative humidity $[24,25]$. We collected the data in fragments of semideciduous seasonal forest whose landscapes have been highly fragmented and altered by agricultural activities, with only $3 \%$ of native forest in different successional stages [26]. The matrix surrounding the fragments was quite diverse, but predominantly sugar cane and pasture crops were cultivated in them [27, 28] (Figure 1).

2.2. Sampling Design. In the study area, we selected six semideciduous seasonal forest fragments, according to the following five criteria: (1) minimum distance of $500 \mathrm{~m}$ between fragments to ensure independence between samples [14], (2) area between 15 and 100 ha, (3) shape index [29] between 1.22 and 2.46 , (4) presence of a water body in or around the fragment, and (5) one of the two predominant types of matrices (over 75\% of the surroundings); that is, in the chosen fragments, sugar cane or pastures prevailed. Thus, we selected three fragments with each of these predominant matrices (Figure 1).

In each of the six fragments, we installed five pitfall traps with drift fences. Each trap array consisted of four $30 \mathrm{~L}$ buckets buried in the ground up to the top of the bucket, with a central one and three radial buckets four meters away from the central bucket and placed at $120^{\circ}$ from each other. These radial buckets were connected to the edge of the central bucket by plastic fences $0.5 \mathrm{~m}$ tall and $4 \mathrm{~m}$ long. Traps were $50 \mathrm{~m}$ from the edge of the fragment and $30 \mathrm{~m}$ apart from each other. We collected the samples over a period of 15 consecutive days in January 2011 and six nonconsecutive days in December 2011, totaling 22,680 trap-hours.

We collected each specimen under IBAMA License no. 1934-1 and we measured with a caliper (accuracy $0.01 \mathrm{~mm}$ ), weighed with a precision balance $(0.1 \mathrm{~g})$, euthanized in saturated cloretona and ethanol in water [30], fixed in $10 \%$ formalin and preserve in $70 \%$ alcohol, according to ethical and legal principles [31, 32]. We preserved the collected material in the Herpetological Collection Alfred Russel Wallace (CHARW) of the Federal University of Alfenas (UnifalMG). Subsequently, we determined the sex of the individuals collected by dissection and direct observation of the gonads.
2.3. Statistical Analyses. We compared the terrestrial amphibian diversity (richness and abundance) between fragments with each of the two predominant matrix types (sugar cane and pasture) by species rarefaction curves [33] with EstimateS 7.5.0 [34] and 500 randomizations. The program generated 500 species accumulation curves, randomizing the order of the samples. Thus, each point on the curve corresponds to the richness average accumulated in the 500 associated curves with a standard deviation. Several studies support this analysis method rather than the use of classical diversity indices $[21,23,33,35,36]$. We compared the observed richness with estimated richness by three nonparametric estimators of EstimateS 7.5.0: Chao 1, Chao 2, and Bootstrap, recommended by different authors $[36,37]$ and used in similar studies with amphibians [21, 23, 36]. We relate the observed and estimated richness through the efficiency measure [36]. We compared the species composition of fragments with different matrix types through the concept of complementarity [23] and significance level according to Silva et al. [19]: values above $50 \%$ indicate high beta diversity. We did not consider exotic species in these analyses.

For biometric analysis, we measured data from snoutvent length (SVL), biomass, and mean biomass/SVL, from individuals of the most abundant species (Rhinella ornata), which we collected in January 2011. This analysis is a more subtle and refined scale for determining the matrix influence on the forest fragment biota [38-40]. After all, before declining and disappearing, a population under impact should show signs of withering, such as reduced average growth or weight loss. The Shapiro-Wilk test rejected the sample normality $(P<0.01$ for all samples), so we compared the measurements of males and females by Mann-Whitney test for each matrix type. We did not find sexual dimorphism, so we pooled sexes for a comparison between the two matrix types by Mann-Whitney. We did not test the sexual dimorphism for the fragments with a predominance of sugar cane because of the low number of males in the sample $(N=$ 2).

\section{Results}

In total, 190 individuals were captured from seven species belonging to five families (Table 1). The most abundant species was Rhinella ornata with 121 specimens $(63.7 \%$ of total individuals). Two species (Odontophrynus cultripes and Leptodactylus mystacinus) had only one or two specimens collected. Of the total number of collected individuals, $87.9 \%$ $(N=167)$ were recorded in predominant pasture fragments and only $12.1 \%(N=23)$ in sugar cane. One recorded species, Lithobates catesbeianus, is non-endemic and, although listed in Table 1, was excluded from further analysis. Excluding this anuran, which is especially abundant and was introduced recently in a single pasture fragment, the difference between amphibian total abundance in fragments with predominant sugar cane and pastures ranged from 101 to 144 . This species alone accounted for $25.7 \%$ of individuals captured in pasture fragments.

Analysis of observed and estimated richness showed relatively little difference between them for sugar cane and 

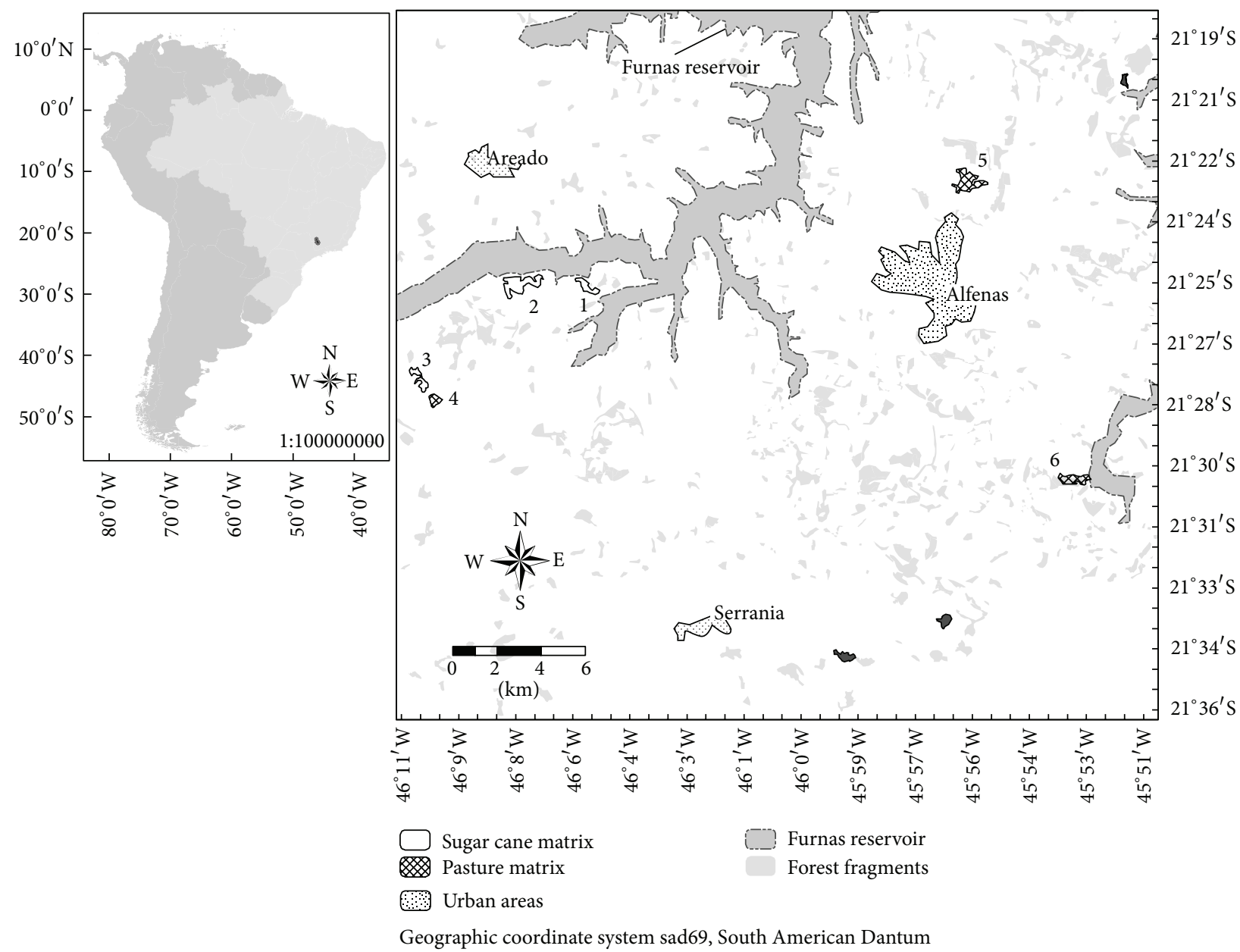

FIGURE 1: Study area location in the surroundings of the cities of urban areas, in the state of Minas Gerais, Brazil, and the six forest fragments sampled.

TABLE 1: List of terrestrial amphibian species and their abundance in fragments of Semi-deciduous seasonal forest with two predominant matrix types (sugar cane and pastures).

\begin{tabular}{lccc}
\hline Species & \multicolumn{2}{c}{ Matrix } & Total \\
\hline $\begin{array}{l}\text { Bufonidae } \\
\quad \text { Shinella ornata }\end{array}$ & 15 & 106 & $\mathbf{1 2 1}$ \\
$\begin{array}{l}\text { Craugastoridae } \\
\quad \text { Haddadus binotatus }\end{array}$ & 4 & 7 & \\
$\begin{array}{l}\text { Cycloramphidae } \\
\quad \text { Odontophrynus cultripes }\end{array}$ & 1 & 0 & $\mathbf{1 1}$ \\
$\quad$ Proceratophrys boiei & 0 & 8 & $\mathbf{8}$ \\
Leptodactylidae & & & \\
$\quad \begin{array}{l}\text { Leptodactylus mystacinus } \\
\text { Physalaemus cuvieri }\end{array}$ & 2 & 0 & $\mathbf{2}$ \\
Ranidae & 1 & 3 & $\mathbf{4}$ \\
$\quad$ Lithobates catesbeianus & 0 & & \\
Total & $\mathbf{2 3}$ & $\mathbf{1 6 7}$ & $\mathbf{1 9 0}$ \\
\hline
\end{tabular}

TABLE 2: Observed species richness $\left(S_{\text {obs }}\right)$, estimated species richness $\left(S_{\text {est }}\right)$ for three estimators and efficiency $\left(S_{\text {obs }} / S_{\text {est }}\right.$ average $)$ of terrestrial amphibians in the fragments of Semi-deciduous seasonal forest with two predominant matrix types (sugar cane and pastures).

\begin{tabular}{|c|c|c|c|c|c|}
\hline \multirow{2}{*}{ Matrix } & \multirow{2}{*}{$S_{\text {obs }}$} & \multicolumn{3}{|c|}{$S_{\text {est }}$} & \multirow{2}{*}{ Efficiency } \\
\hline & & Chao 1 & Chao 2 & Bootstrap & \\
\hline Sugar cane & 5 & 5.5 & 5.32 & 6 & 0.89 \\
\hline Pasture & 4 & 4 & 4 & 4.25 & 0.97 \\
\hline
\end{tabular}

pasture, with efficiencies greater than $85 \%$ (Table 2). This result indicates that the sampling effort was sufficient.

The complementarity value was $50 \%$. In other words, half of the species of the sugar cane fragment list differed from the list of the fragments with pastures. On average, matrices of sugar cane and pastures showed little permeable traffic for half of amphibian species observed.

Like the comparison of observed and estimated richness, sample-based rarefaction curves (Figure 2) indicate that the sampling effort was sufficient, with the two matrix types tending to stabilize. Individual-based rarefaction curves 


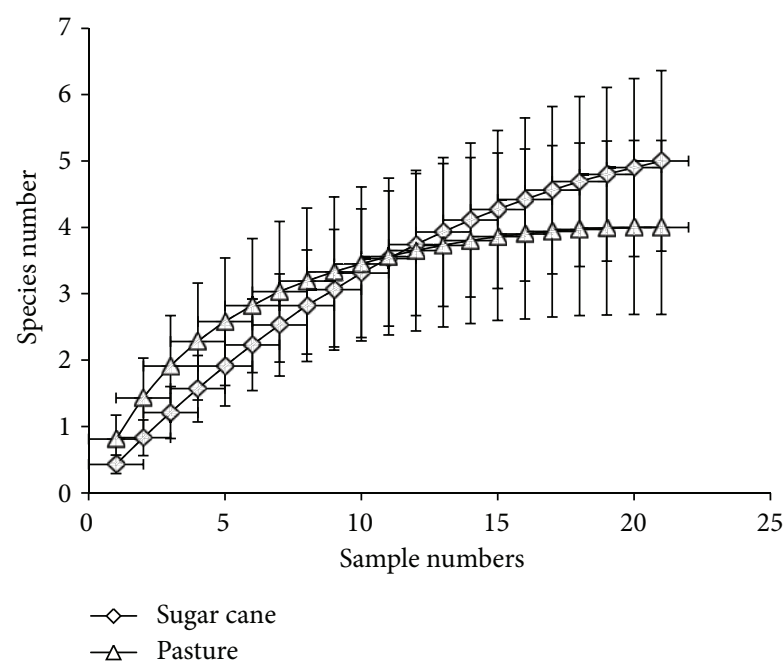

FIGURE 2: Sample-based rarefaction curves of terrestrial amphibians in fragments of Semideciduous Seasonal Forest with three predominant matrix types (sugar cane and pasture), estimated from 500 randomizations in the order of the samples.

(Figure 3) support the results of Table 1: richness relatively is constant, but relative abundance is very different. Sugar cane fragments exhibited the lowest individual number.

Rhinella ornata biometric analysis detected no sexual dimorphism in relation to biomass (pasture: $U=459.5$, $Z(U)=1.099, P=0.498)$, snout-vent length (SVL) (pasture: $U=447.5, Z(U)=0.817, P=0.414)$, nor to ratio biomass/SVL (pasture: $U=462.5, Z(U)=0.642, P=$ $0.521)$. Also no biometric differences were observed between fragments with the two predominant matrix types (biomass: $U=461.5, Z(U)=0.47, P=0.64$; SVL: $U=477$, $Z(U)=0.29, P=0.76$; biomass/SVL: $U=450, Z(U)=0.59$, $P=0.55)$.

\section{Discussion}

Forest fragments surrounded by two predominant matrix types (sugar cane and pastures) showed constant values of terrestrial amphibian richness, but the total abundance varied greatly. The lowest individual number was present in fragments surrounded by sugar cane, about seven times less than that in fragments with pasture. Some studies indicate that abundance is a more efficient bioindicator parameter than richness $[22,41]$. The search for species richness differences may mask other processes and generate inefficient conservation plans [19]. One reason for this may be a generalist species presence occupying disturbed areas, which can artificially inflate species richness $[42,43]$.

Fragments surrounded by sugar cane with low abundance may be the result of management practices used in this cultivation and not in the other two activities. Although the pastures are more like open habitats, they can be considered relatively perennial. Sugar cane management, in turn, requires cutting stalks every year or one and a half years, producing instant and drastic changes in the landscape.

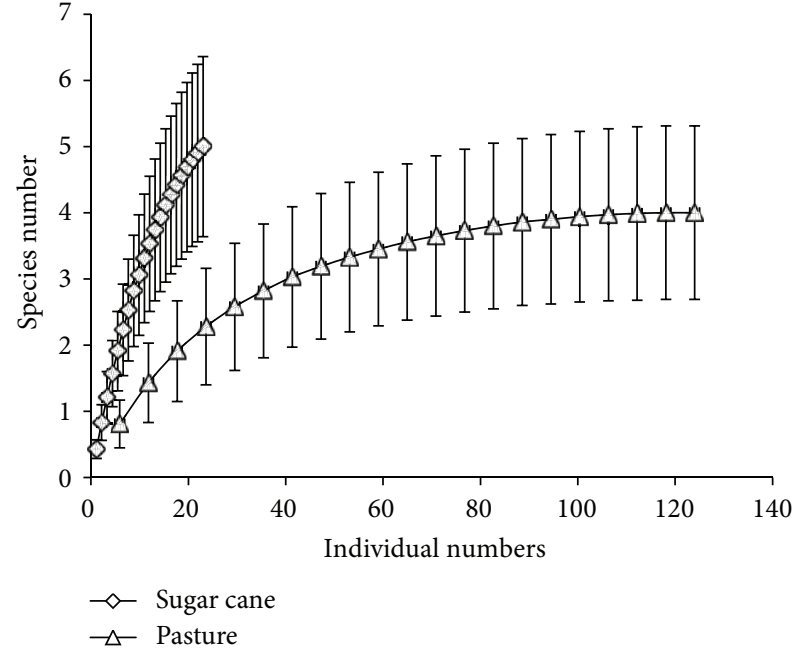

FIGURE 3: Individual-based rarefaction curves of terrestrial amphibians in fragments of Semideciduous Seasonal Forest with three predominant matrix types (sugar cane and pasture), estimated from 500 randomizations in the order of the samples.

Suddenly after cutting, amphibians of the fragment, which explore the sugar cane plantation in search of resources or simply use it as a transit corridor to reach breeding areas, are more exposed to predators [44], high UV-B radiation [45], high temperatures, and low air humidity [46].

Another management practice used in sugar cane is fire. Several negative impacts from slash-and-burn practices have been reported for amphibians and other organisms $[47,48]$, but this method is still used in certain agricultural activities. Cattle ranchers sometimes use this technique to clear forest or brush area and thus facilitate establishing pasture. However, afterwards, controlled burning is not used. Currently in sugar cane fields, the practice of burning straw to facilitate harvesting is widely used throughout the year [49]. Individual amphibian deaths from such fires appear to be rare events $[50,51]$, because it is easy for them to find refuge [52]. However modification or destruction of habitats used for foraging, shelter, and reproduction is very common. In semideciduous seasonal forests, fire has a deleterious effect on anuran litter richness and abundance. After the fire, the leaves, which again cover the ground, are compressed litter that does not retain moisture, making amphibian recolonization difficult [39]. Another fire hazard is the possibility of reaching vegetation close to the sugar cane fields and eliminating natural predators of some pests, requiring greater herbicide and pesticide use to control weeds that grow rapidly after burning [53].

Sugar cane is one of the main consumers of herbicides and pesticides in Brazil [54]. Pastures, in turn, employ no pesticides. The herbicide, Tebuthiuron, used exclusively in sugar cane farming, can cause weight loss [55], relating directly to amphibian health or adaptability [56]. Another widely used herbicide in sugar cane is Diuron, which causes deformities in embryos and tadpoles, affecting amphibian 
growth and survival [57]. The amount and type of pesticides used around fragments may explain the terrestrial amphibians low abundance associated with sugar cane compared to fragments surrounded by pastures.

The expected negative effects of pasture [19], contradicted by our results, may be simply due to the larger number of studies about amphibians and pastures [19, 21, 22, 43, 58-63] than in other matrix types [64-67]. Studies on sugar cane effects in amphibians are particularly scarce. This matrix, when studied, was never exclusively or quantitatively analyzed and always embedded in a matrix being predominantly covered in pasture $[19,60,63,67-69]$. Still, some studies have shown that temporary ponds or lagoons in pasture areas (often used as a cattle water source) are an important resource as breeding sites for several amphibians species and may be an important management strategy for conservation purposes. However, the recent sugar cane boom has reduced this possibility $[63,64]$. At least for studies in Brazil, the large number of pasture studies may reflect this matrix being predominant compared to agricultural crops: $9 \%$ of the country is occupied by sugar cane fields, while pastures cover over $20 \%$ of the territory [70].

Another aspect that should be considered when comparing fragments surrounded by different predominant matrices is species composition, which enables distinguishing matrix effects on different species groups, such as, for instance, generalist, exotic, and specialist. Many of the species observed in the sampled fragments are generalists and theoretically less dependent on forest environments. It can be argued that the occurrence of many of these species is favored by deforestation and the formation of open areas resulting from land use activities [40]. This is undoubtedly the case for Physalaemus cuvieri $[43,65,68,71-74]$. Other species are not so exclusively characteristic of open areas but have generalist habits, being found both in disturbed habitats, as well as in forests, as Odontophrynus cultripes [72, 74, 75] and Leptodactylus mystacinus $[65,69,73,76]$.

It is important to note, however, two aspects of the considered generalist species: (1) areas with marked climatic seasonality (as many semideciduous forests) may present natural predominance of these species, not only for the forest land conversion into cultivated areas [43] and (2) even for such species, forest fragments are fundamental as refuge areas during the dry season, shelter during the reproductive period or as a source of food resources [60]. Although they are generalist species, these species may also be affected by certain matrix types. Of all the species considered generalists in our study, two (O. cultripes and L. mystacinus) were recorded in low numbers, which does not allow generalizations, but two P. cuvieri confirmed the trend of low abundance in fragments with predominance of sugar cane.

Exotic species many times also show generalist behavior. The bullfrog, Lithobates catesbeianus, fits this situation. It was present in the study area, only in fragment 5 , with pasture being the predominant matrix. It was the third most abundant species in this study, with 43 specimens found. This frog was introduced in several locations in Brazil and the world, from frog farms for meat production. This species has had negative consequences for native assemblages [71, 77].
During our study, this species was released by the owner at a lake adjacent to the fragment to serve as a food source. It was possible to observe the individual recruitment and population growth at the site. Compared to other records of the species in Brazil [77], this is the first record in the Alfenas region.

Species composition analyses and their ecological requirements are also important for positive biomarker identification. In this case, it would be a more demanding species, associated with forest environments and theoretically more sensitive to the fragmentation effects and less permeable matrices, such as Haddadus binotatus [71, 73, 74], Proceratophrys boiei $[65,71,74,78]$, and Rhinella ornata $[69,71,73,76,78]$. These three species were present in low abundance or absent, case of $P$. boiei, in fragments surrounded by sugar cane contributing to the conclusion that a sugar cane matrix is inhospitable to the more demanding species.

The number of individuals of $H$. binotatus recorded in fragments with pasture is almost double the abundance in fragments with sugar cane. Nevertheless, the total abundance of this species was underestimated because individuals can escape pitfall traps by jumping or climbing out of the bucket $[71,79]$. But, considering that this ability to escape is species intrinsic and it is not affected by the matrix surrounding the fragments, their relative abundance can be compared. Proceratophrys boiei is the second most abundant species and absent in sugar cane fragments. One possibility is that this species has suffered a decline to the point of local extinction in these fragments. Rhinella ornata is the first in abundance as in [71] and, although present in fragments surrounded by sugar cane, the number of individuals in fragments with this matrix type was minimal. However, the expectation of finding biometric differences between samples, particularly with smaller individuals in fragments surrounded by sugar cane, was not supported. Maybe this kind of difference, because it is more subtle, requires more refined data and analysis, for instance, geometric morphometric, which considers not only the size but also the shape and the symmetry of the body [80].

Another hypothesis is that $R$. ornata is not a forest bioindicator or forest species as previously thought. Some studies confirm this species as a forest species and being associated with the Atlantic Rainforest biome lato sensu, however with great ecological plasticity and high dispersal capacity, also occupying disturbed habitats and urban areas $[75,81]$. Species capable of using the matrix or at least those species that tolerate matrix effects, normally maintain stable population or may even grow [1]. Although $R$. ornata can provide large displacement capacity and dominate numerically varied environments, we do not believe that this species is immune to any kind of matrix. This species has been losing habitats in the state of São Paulo due to sugar cane expansion [69], and some isolated population has no gene flow between them [82]. The low abundance observed in fragments surrounded by sugar cane in the present study confirms the possibility that this species and other terrestrial amphibians are negatively affected by the advance of sugar cane. 


\section{Conflict of Interests}

The authors declare that there is no conflict of interests regarding the publication of this paper.

\section{Acknowledgments}

The authors wish to thank Unifal-MG for transportation, Felipe Bassega, Natália Sampaio, Anna Monti, Izabela Ferreira, Luís Zingra, Gabriel Fonoff, Ana Pugina, Luis Oliveira, Anderson Nunes, Paula Nunes, and Carla Pádua and Vinícius Heÿden for field assistance with trap placement and help in collection, Fabio Freire Diniz, Mariana Raniero and Marco Túlio Pacheco for making the map and for yielding some data, Marcos Vital for help with the analysis of rarefaction curves, CNPq (Process N. 472250/2010-8) for financial support, FAPEMIG/VALE SA (Process N. RDP00104-10) for financial support and the masters scholarship, Alex Bager, Flavio N. Ramos, and Luciana B. Nascimento for revision of the paper, and James Hesson of http://www.academicenglishsolutions.com/ for English revision.

\section{References}

[1] C. Gascon, T. E. Lovejoy, R. O. Bierregaard Jr. et al., "Matrix habitat and species richness in tropical forest remnants," Biological Conservation, vol. 91, no. 2-3, pp. 223-229, 1999.

[2] T. H. Ricketts, "The matrix matters: effective isolation in fragmented landscapes," American Naturalist, vol. 158, no. 1, pp. 87-99, 2001.

[3] E. B. Viveiros de Castro and F. A. S. Fernandez, "Determinants of differential extinction vulnerabilities of small mammals in Atlantic forest fragments in Brazil," Biological Conservation, vol. 119, no. 1, pp. 73-80, 2004.

[4] T. D. Sisk, N. M. Haddad, and P. R. Ehrlich, "Bird assemblages in patchy woodlands: modeling the effects of edge and matrix habitats," Ecological Applications, vol. 7, no. 4, pp. 1170-1180, 1997.

[5] O. Berry, M. D. Tocher, D. M. Gleeson, and S. D. Sarre, "Effect of vegetation matrix on animal dispersal: genetic evidence from a study of endangered skinks," Conservation Biology, vol. 19, no. 3, pp. 855-864, 2005.

[6] Y. Haila, "A conceptual genealogy of fragmentation research: from island biogeography to landscape ecology," Ecological Applications, vol. 12, no. 2, pp. 321-334, 2002.

[7] J. R. Malcolm, The small mammals of Amazonian forest fragments: pattern and process [Ph.D. thesis], University of Florida, Gainesville, Fla, USA, 1991.

[8] J. I. Watling, A. J. Nowakowski, M. A. Donnelly, and J. L. Orrock, "Meta-analysis reveals the importance of matrix composition for animals in fragmented habitat," Global Ecology and Biogeography, vol. 20, no. 2, pp. 209-217, 2011.

[9] M. J. Brady, C. A. McAlpine, H. P. Possingham, C. J. Miller, and G. S. Baxter, "Matrix is important for mammals in landscapes with small amounts of native forest habitat," Landscape Ecology, vol. 26, no. 5, pp. 617-628, 2011.

[10] J. Mohd-Azlan and M. J. Lawes, "The effect of the surrounding landscape matrix on mangrove bird community assembly in north Australia," Biological Conservation, vol. 144, no. 9, pp. 2134-2141, 2011.
[11] G. Santos-Barrera and J. N. Urbina-Cardona, "The role of the matrix-edge dynamics of amphibian conservation in tropical montane fragmented landscapes," Revista Mexicana de Biodiversidad, vol. 82, no. 2, pp. 679-687, 2011.

[12] M. Antongiovanni and J. P. Metzger, "Influence of matrix habitats on the occurrence of insectivorous bird species in Amazonian forest fragments," Biological Conservation, vol. 122, no. 3, pp. 441-451, 2005.

[13] W. E. Duellman and L. Trueb, Biology of Amphibians, The Johns Hopkins University Press, Baltimore, MD, USA, 1994.

[14] L. J. Vitt and J. P. Caldwell, "Spacing, movements, and orientation," in Herpetology: An Introductory Biology of Amphibians and Reptiles, L. J. Vitt and J. P. Caldwell, Eds., pp. 217-238, Academic Press, San Diego, Calif, USA, 2009.

[15] R. D. Semlitsch and T. J. Ryan, "Migration, amphibian," in The Encyclopedia of Reproduction, E. Knobil and J. D. Neill, Eds., pp. 221-227, Academic Press, New York, NY, USA, 1998.

[16] J. H. K. Pechmann, D. E. Scott, R. D. Semlitsch, J. P. Caldwell, L. J. Vitt, and J. W. Gibbons, "Declining amphibian populations: the problem of separating human impacts from natural fluctuations," Science, vol. 253, no. 5022, pp. 892-895, 1991.

[17] S. N. Stuart, J. S. Chanson, N. A. Cox et al., "Status and trends of amphibian declines and extinctions worldwide," Science, vol. 306, no. 5702, pp. 1783-1786, 2004.

[18] K. R. Lips, F. Brem, R. Brenes et al., "Emerging infectious disease and the loss of biodiversity in a Neotropical amphibian community," Proceedings of the National Academy of Sciences of the United States of America, vol. 103, no. 9, pp. 3165-3170, 2006.

[19] R. A. Silva, I. A. Martins, and D. D. C. Rossa-Feres, "Environmental heterogeneity: anuran diversity in homogeneous environments," Zoologia, vol. 28, no. 5, pp. 610-618, 2011.

[20] S. Neckel-Oliveira, "Effects of landscape change on clutches of Phyllomedusa tarsius, a neotropical treefrog," Biological Conservation, vol. 118, no. 1, pp. 109-116, 2004.

[21] P. J. Isaacs Cubides and J. N. Urbina Cardona, "Anthropogenic disturbance and edge effects on anuran assemblages inhabiting cloud forest fragments in Colombia," Natureza a Conservacao, vol. 9, no. 1, pp. 39-46, 2011.

[22] J. N. Urbina-Cardona, M. Olivares-Pérez, and V. H. Reynoso, "Herpetofauna diversity and microenvironment correlates across a pasture-edge-interior ecotone in tropical rainforest fragments in the Los Tuxtlas Biosphere Reserve of Veracruz, Mexico," Biological Conservation, vol. 132, no. 1, pp. 61-75, 2006.

[23] E. Pineda and G. Halffter, "Species diversity and habitat fragmentation: frogs in a tropical montane landscape in Mexico," Biological Conservation, vol. 117, no. 5, pp. 499-508, 2004.

[24] G. M. Drummond, C. S. Martins, A. B. M. Machado, F. A. Sebaio, and Y. Antonini, Biodiversidade em Minas Gerais: um atlas para sua conservação, Fundação Biodiversitas, Belo Horizonte, Brazil, 2005.

[25] F. T. Martins, M. H. Santos, M. Polo, and L. C. A. Barbosa, "Variação química do óleo essencial de Hyptis suaveolens (L.) Poit., sob condições de cultivo," Química Nova, vol. 29, pp. 12031209, 2006.

[26] J. P. R. Capobianco, "Situação atual e perspectivas para a conservação da Mata Atlântica," in Aspectos jurídicos da proteção da Mata Atlântica, A. Lima, Ed., pp. 9-15, Instituto Socioambiental, São Paulo, Brazil, 2001.

[27] Fundação SOS Mata Atlântica and Instituto Nacional de Pesquisas Espaciais, "Atlas dos remanescentes florestais da Mata Atlântica, 2008-2010," 2012, http://www.inpe.br/noticias/ arquivos/pdf/atlasrelatoriofinal.pdf. 
[28] IBGE, Banco de Dados Agregados. Sistema IBGE de Recuperação Automática (SIDRA), 2012, http://www.sidra.ibge .gov.br/.

[29] K. Mcgarigal and B. Marks, FRAGSTATS: Spatial Pattern Analysis Program for Quantifying Landscape Structure, U.S. Department of Agriculture, Forest Service, Pacific Northwest Research Station, Portland, Ore, USA, 1994.

[30] C. C. Cortez, A. M. Suárez-Mayorga, and F. J. López-López, "Preparación y preservación de material científico," in Técnicas de inventario y monitoreo para los anfíbios de la región tropical andina, A. Angulo, J. V. Rueda-Almonacid, J. V. RodríguezMahecha, and E. La Marca, Eds., pp. 173-221, Panamericana Formas e Impresos S.A., Bogotá, Colombia, 2006.

[31] M. E. V. Calleffo, "Anfíbios," in Técnicas de coleta e preparação de vertebrados, P. Auricchio, Ed., pp. 43-74, 2002.

[32] F. L. Franco, M. G. Salomao, and P. Auricchio, "Répteis," in Técnicas de coleta e preparação de vertebrados, P. Auricchio and M. G. Salomao, Eds., pp. 75-11, Instituto Pau e de História Natural, Aruja, Brazil, 2002.

[33] N. J. Gotelli and R. K. Colwell, "Quantifying biodiversity: procedures and pitfalls in the measurement and comparison of species richness," Ecology Letters, vol. 4, no. 4, pp. 379-391, 2001.

[34] R. K. Colwell, "EstimateS: statistical estimation of species richness and shared species from sample, version 8.2," 2012, http://purl.oclc.org/estimates .

[35] A. S. Melo, R. A. S. Pereira, A. J. Santos et al., "Comparing species richness among assemblages using sample units: why not use extrapolation methods to standardize different sample sizes?" Oikos, vol. 101, no. 2, pp. 398-410, 2003.

[36] J. I. Watling and M. A. Donnelly, "Multivariate correlates of extinction proneness in a naturally fragmented landscape," Diversity and Distributions, vol. 13, no. 4, pp. 372-378, 2007.

[37] A. E. Magurran, Measuring Biological Diversity, Blackwell Publishing, Oxford, UK, 2004.

[38] M. V. Lomolino and D. R. Perault, "Island biogeography and landscape ecology of mammals inhabiting fragmented, temperate rain forests," Global Ecology and Biogeography, vol. 10, no. 2, pp. 113-132, 2001.

[39] D. S. Moen and J. J. Wiens, "Phylogenetic evidence for competitively driven divergence: body-size evolution in caribbean treefrogs (Hylidae: Osteopilus)," Evolution, vol. 63, no. 1, pp. 195-214, 2009.

[40] M. A. L. Zuffi, S. Fornasiero, R. Picchiotti, P. Poli, and M. Mele, "Adaptive significance of food income in European snakes: body size is related to prey energetics," Biological Journal of the Linnean Society, vol. 100, no. 2, pp. 307-317, 2010.

[41] A. A. Giaretta, K. G. Facure, R. J. Sawaya, J. H. M. de Meyer, and N. Chemin, "Diversity and abundance of litter frogs in a montane forest of southeastern Brazil: seasonal and altitudinal changes," Biotropica, vol. 31, no. 4, pp. 669-674, 1999.

[42] C. F. B. Haddad and A. S. Abe, "Anfíbios e Répteis," Workshop Mata Atlântica e Campos Sulinos, 1999, http://fat.org.br/workshop/mata.atlantica/BR/rfinais/rt_anfibios.

[43] T. G. Santos, D. C. Rossa-Feres, and L. Casatti, "Diversidade e distribuição espaço-temporal de anuros em região com pronunciada estação seca no sudeste do Brasil," Iheringia Série Zoologia, vol. 97, pp. 37-49, 2007.

[44] M. Denoel, G. Dzukic, and M. L. Kalezic, "Effects of widespread fish introductions on paedomorphic newts in Europe," Conservation Biology, vol. 19, no. 1, pp. 162-170, 2005.
[45] B. A. Bancroft, N. J. Baker, and A. R. Blaustein, "A meta-analysis of the effects of ultraviolet $\mathrm{B}$ radiation and its synergistic interactions with $\mathrm{pH}$, contaminants, and disease on amphibian survival," Conservation Biology, vol. 22, no. 4, pp. 987-996, 2008.

[46] M. R. Preest and F. H. Pough, "Effects of body temperature and hydration state on organismal performance of toads, Bufo americanus," Physiological and Biochemical Zoology, vol. 76, no. 2, pp. 229-239, 2003.

[47] C. N. Spencer and F. R. Hauer, "Phosphorus and nitrogen dynamics in streams during a wildfire," Journal of the North American Benthological Society, vol. 10, pp. 24-30, 1991.

[48] G. W. Minshall, C. T. Robinson, and D. E. Lawrence, "Postfire responses of lotic ecosystems in Yellowstone National Park, USA," Canadian Journal of Fisheries and Aquatic Sciences, vol. 54, no. 11, pp. 2509-2525, 1997.

[49] M. Santaella and L. A. D. Paes, "Utilização do fogo em cultura de cana-de-açúcar," 2012, http://www.ipef.br/publicacoes/ forum_incendios/cap02.pdf.

[50] K. R. Russell, D. H. van Lear, and D. C. Guynn Jr., "Prescribed fire effects on herpetofauna: review and management implications," Wildlife Society Bulletin, vol. 27, no. 2, pp. 374-384, 1999.

[51] J. K. Smith, "Wildland fire in ecosystems: effects of fire on fauna," Tech. Rep. RMRS-42-1, USDA Forest Service General, 2000.

[52] G. R. Friend, "Impact of fire on small vertebrates in mallee woodlands and heathlands of temperate Australia: a review," Biological Conservation, vol. 65, no. 2, pp. 99-114, 1993.

[53] R. Rossetto and A. D. Santiago, "Manejo do canavial," Impactos do canavial, 2012, http://www.embrapa.br/.

[54] C. A. Spadotto and M. A. F. Gomes, "Agrotóxicos no Brasil," Impactos do canavial, 2012, http://www.embrapa.br/.

[55] M. H. Boily, V. E. Bérubé, P. A. Spear, C. DeBlois, and N. Dassylva, "Hepatic retinoids of bullfrogs in relation to agricultural pesticides," Environmental Toxicology and Chemistry, vol. 24, no. 5, pp. 1099-1106, 2005.

[56] R. Altwegg and H.-U. Reyer, "Patterns of natural selection on size at metamorphosis in water frogs," Evolution, vol. 57, no. 4, pp. 872-882, 2003.

[57] G. S. Schuytema and A. V. Nebeker, "Comparative effects of ammonium and nitrate compounds on pacific treefrog and african clawed frog embryos," Archives of Environmental Contamination and Toxicology, vol. 36, no. 2, pp. 200-206, 1999.

[58] T. S. Vasconcelos and D. C. Rossa-Feres, "Diversidade, distribuição espacial e temporal de anfíbios anuros (Amphibia, Anura) na região noroeste do estado de São Paulo, Brasil," Biota Neotropica, vol. 5, no. 2, pp. 1-14, 2005.

[59] S. Neckel-Oliveira and C. Gascon, "Abundance, body size and movement patterns of a tropical treefrog in continuous and fragmented forests in the Brazilian Amazon," Biological Conservation, vol. 128, no. 3, pp. 308-315, 2006.

[60] F. R. Silva and D. C. Rossa-Feres, "The use of forest fragments by open-area anurans (Amphibia) in northwestern São Paulo State, Brazil," Biota Neotropica, no. 7, pp. 141-148, 2007.

[61] P. S. Bernarde and L. C. Macedo, "Impacto do desmatamento e formação de pastagens sobre a anurofauna de serapilheira em Rondônia," Iheringia Série Zoologia, vol. 98, pp. 454-459, 2008.

[62] M. V. Garey and V. X. Silva, "Spatial and temporal distribution of anurans in an agricultural landscape in the Atlantic Semideciduous Forest of South American," Journal of Herpetology, vol. 5, pp. 64-72, 2010. 
[63] F. R. Silva, J. P. Gibbs, and D. C. Rossa-Feres, "Breeding habitat and landscape correlates of frog diversity and abundance in a tropical agricultural landscape," Wetlands, vol. 31, no. 6, pp. 1079-1087, 2011.

[64] F. R. Silva, T. A. L. Oliveira, J. P. Gibbs, and D. C. RossaFeres, "An experimental assessment of landscape configuration effects on frog and toad abundance and diversity in tropical agro-savannah landscapes of southeastern Brazil," Landscape Ecology, vol. 27, no. 1, pp. 87-96, 2012.

[65] J. Zina, J. Ennser, S. C. P. Pinheiro, C. F. B. Haddad, and L. F. Toledo, "Taxocenose de anuros de uma mata semidecídua do interior do Estado de São Paulo e comparações com outras taxocenoses do Estado, sudeste do Brasil," Biota Neotropica, vol. 7, pp. 49-58, 2007.

[66] F. R. da Silva, R. S. Santos, M. A. Nunes, and D. D. C. RossaFeres, "Anuran captured in pitfall traps in three agrossystems in northwestern São Paulo State, Brazil," Biota Neotropica, vol. 9, no. 4, pp. 253-255, 2009.

[67] M. Nelson, S. Silverstone, K. C. Reiss et al., "The impact of hardwood line-planting on tree and amphibian diversity in a secondary subtropical wet forest of Southeast Puerto Rico," Journal of Sustainable Forestry, vol. 29, no. 5, pp. 503-516, 2010.

[68] P. S. Bernarde and M. N. C. Kokubum, "Anurofauna do Município de Guararapes, Estado de São Paulo, Brasil (Amphibia: Anura)," Acta Biologica Leopoldensia, vol. 21, no. 1, pp. 89-97, 1999.

[69] V. H. M. Prado, F. R. Silva, N. Y. N. Dias, J. S. R. Pires, and D. C. Rossa-Feres, "Anura, Estação Ecológica de Jataí, São Paulo state, southeastern Brazil," Check List, vol. 5, pp. 495-502, 2009.

[70] IBGE, "Censo agropecuário de 2006," 2012, http://www.ibge .gov.br/home/presidencia/noticias/noticia_visualiza.php?id_noticia $=1064$ andid_pagina $=1$.

[71] M. Dixo and V. K. Verdade, "Herpetofauna de serrapilheira da Reserva Florestal de Morro Grande, Cotia (SP)," Biota Neotropica, vol. 6, no. 2, pp. 1-20, 2006.

[72] C. O. Araújo, T. H. Condez, and R. J. Sawaya, "Anfíbios anuros do Parque Estadual das Furnas do Bom Jesus, sudeste do Brasil, e suas relações com outras taxocenoses no Brasil," Biota Neotropica, vol. 2, pp. 77-98, 2009.

[73] R. A. Brassaloti, D. de Cerqueira Rossa-Feres, and J. Bertoluci, "Anuran fauna of the Semideciduous Forest of the Estação Ecológica dos Caetetus, Southeastern Brazil," Biota Neotropica, vol. 10, no. 1, pp. 275-291, 2010.

[74] M. R. Moura, A. P. Motta, V. D. Fernandes, and R. N. Feio, "Herpetofauna from Serra do Brigadeiro, an Atlantic Forest remain in the state of Minas Gerais, Southeastern Brazil," Biota Neotropica, vol. 12, pp. 209-235, 2012.

[75] J. Bertoluci, M. A. S. Canelas, C. C. Eisemberg, C. F. D. S. Palmuti, and G. G. Montingelli, "Herpetofauna of Estação Ambiental de Peti, an Atlantic Rainforest fragment of Minas Gerais State, southeastern Brazil," Biota Neotropica, vol. 9, no. 1, pp. 147-156, 2009.

[76] T. G. Santos, T. S. Vasconcelos, and C. F. B. Haddad, "The role of environmental heterogeneity in maintenance of anuran amphibian diversity of the Brazilian Mesophytic Semideciduous Forest," in Tropical Forests, P. Sudarshana, M. NageswaraRao, and J. R. Soneji, Eds., chapter 7, pp. 119-138, InTech, 2012.

[77] C. Both, R. Lingnau, A. Santos Jr., B. Madalozzo, L. P. Lima, and T. Grant, "Widespread occurrence of the American Bullfrog, Lithobates catesbeianus (Shaw, 1802) (Anura: Ranidae), in Brazil," South America Journal of Herpetology, vol. 6, no. 2, pp. 127-134, 2011.
[78] T. G. dos Santos, T. D. S. Vasconcelos, D. D. C. Rossa-Feres, and C. F. B. Haddad, "Anurans of a seasonally dry tropical forest: Morro do Diabo State Park, São Paulo state, Brazil," Journal of Natural History, vol. 43, no. 15-16, pp. 973-993, 2009.

[79] M. Dixo and M. Martins, "Are leaf-litter frogs and lizards affected by edge effects due to forest fragmentation in Brazilian Atlantic forest?" Journal of Tropical Ecology, vol. 24, no. 5, pp. 551-554, 2008.

[80] A. M. Lawing and P. D. Polly, "Geometric morphometrics: recent applications to the study of evolution and development," Journal of Zoology, vol. 280, no. 1, pp. 1-7, 2010.

[81] J. W. Ribeiro-Junior and J. Bertoluci, "Anuros do cerrado da Estação Ecológica e da Floresta Estadual de Assis, sudeste do Brasil," Biota Neotropica, vol. 9, no. 1, pp. 1-9, 2009.

[82] M. Dixo, J. P. Metzger, J. S. Morgante, and K. R. Zamudio, "Habitat fragmentation reduces genetic diversity and connectivity among toad populations in the Brazilian Atlantic Coastal Forest," Biological Conservation, vol. 142, no. 8, pp. 1560-1569, 2009. 

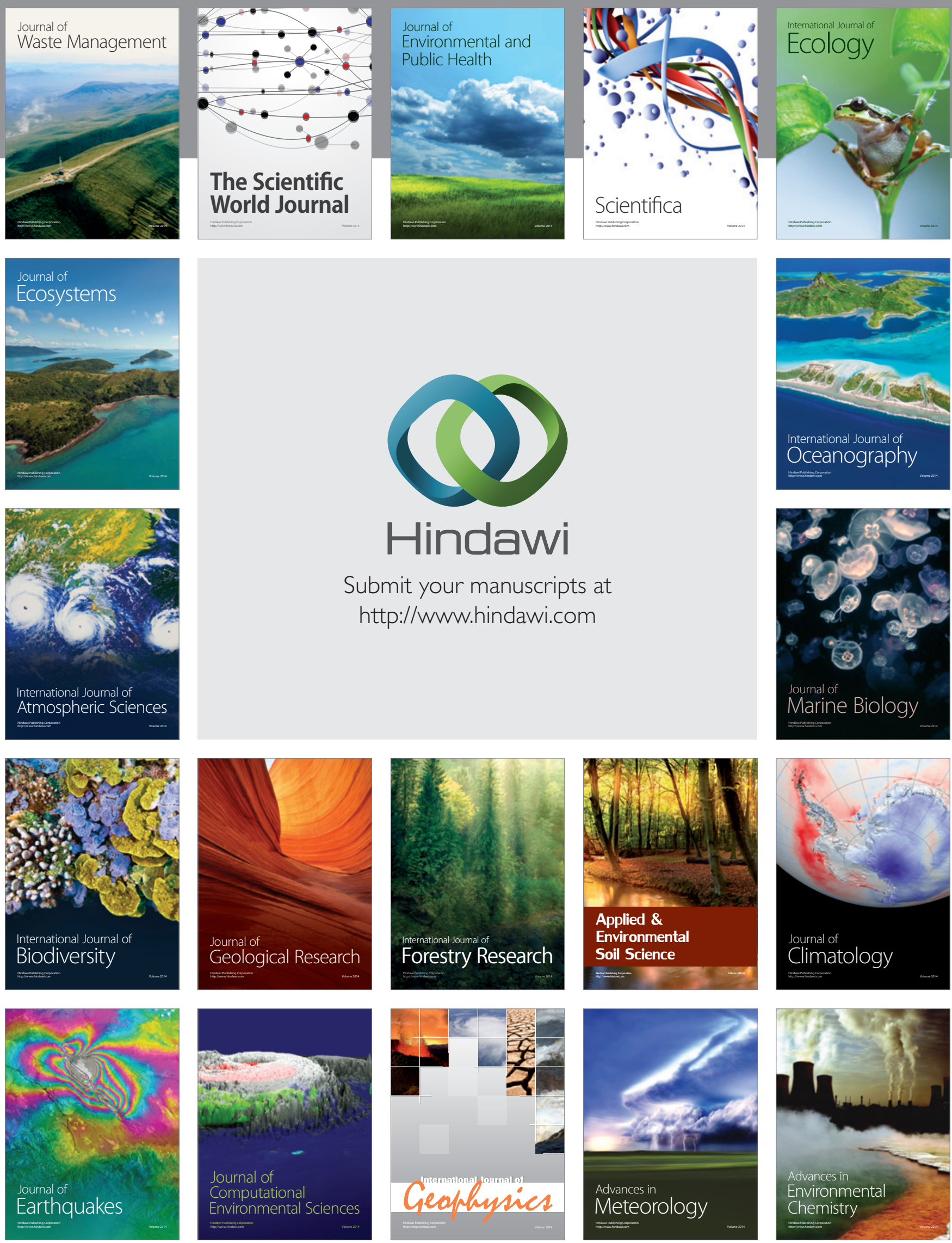